Марија Лончар ${ }^{1}$

Универзитет у Београду

Филолошки факултет
УдК $81 ' 246.2$

DOI https://doi.org/10.18485/zivjez.2017.37.1.7

Прегледни научни рад

\title{
БИЛИНГВАЛНА НАСТАВА \\ НА НЕМАЧКОМ И СРПСКОМ ЈЕЗИКУ \\ НА ПРИМЕРИМА ОШ „10. ОКТОБАР“ У СУБОТИЦИ, ПРВЕ НИШКЕ ГИМНАЗИЈЕ „СТЕВАН СРЕМАЦ“ И ВАЉЕВСКЕ ГИМНАЗИЈЕ
}

Билингвална настава у Србији резултат је примене савремених тенденција високих европских институција са циљем стварања плурилингвалних појединаца и мултикултурног друштва. Од увођења двојезичне наставе у српски образовни систем 2004/2005. године, интересовање за овим обликом наставе постаје све веће, а његове предности препознаје читаво друштво. Од пре неколико година двојезична настава се изводи и на немачком и српском језику (поред комбинација српски - италијански / француски/ енглески /руски) и то на различитим образовним нивоима - у основним школама, гимназијама, па чак и у предшколским установама².

У раду се описује примена двојезичне наставе на немачком и српском језику у ОШ „10. октобар“ у Суботици, Првој нишкој гимназији „Стеван Сремац“ и Ваљевској гимназији. Резултати анкетираних наставника и директора показују низ предности, али и недостатке у погледу евалуације, наставног материјала и подршке наставницима, као и континуираног двојезичног образовања. Циљ рада јесте да укаже на тренутну слику и актуелне изазове везане за спровођење наставе на српском и немачком како би приступ кроз целокупан двојезични образовни процес био систематичнији.

119arija164@yahoo.com

2 У вртићу „Палчица“ ПУ „Наша радост“ у Суботици школске 2002/2003. било је пет двојезичних група. Данас се двојезични програм реализује на српском и мађарском, српском и немачком, као и мађарском и немачком језику. Од 2012. се у вртићу „Петар Пан“ у Панчеву у оквиру припремне наставе за први разред одвија двојезична настава на српском и енглеском језику. Деца која учествују у овом двојезичном програму имају могућност да наставе са двојезичним образовањем, такође на српском и енглеском језику, у ОШ „Свети Сава“ у Панчеву. 
Кључне речи: двојезична/билингвална настава, двојезично/ билингвално образовање, вехиколарни језик, CLIL, плурилингвизам, вишејезичност, мултикултурализам, имерзија, образовна језичка политика.

Европска образовна језичка политика заснива се на очувању и промовисању разноликости будући да је Европа мултиетничка, мултикултурална, а самим тим и вишејезична средина. Ослањајући се на ту чињеницу, Европска комисија (2004: 10) оцењује да је способност да се разуме и комуницира на различитим језицима тренутно једна од основних вештина која је грађанима потребна уколико желе да активно учествују у европском друштву. Европска комисија притом не говори само о учењу тзв. „великих“ језика, већ говори и о језицима са знатно мањим бројем изворних говорника на тлу Европе како би се задовољиле језичке потребе свих грађана на сваком тржишту. Учењем и усвајањем језика и развијањем комуникативних компетенција на најмање два језика поред матерњег остварује се идеја Савета Европе о вишејезичном грађанину, тј. плурилингвалном појединцу који на различитим језицима комуницира из личних, образовних, пословних, професионалних или других разлога (Филиповић 2009: 71). У школском систему, поред редовних часова првог, другог, а понегде и трећег страног језика, вишејезичност се као циљ сваког грађанина Европе реализује и кроз двојезичну или билингвалну наставу. Овде се говори о настави која се одвија паралелно на два језика методом CLIL - интегрисаног учења садржаја и језика и то у комбинацији немачки-српски.

Рад се састоји из четири дела. Први део говори о језичкој политици Европске уније и даје теоријска одређења важна за облик двојезичне наставе, други се тиче правних тј. законских одредби у вези са двојезичном наставом у Србији. Трећи део описује примену билингвалне наставе на немачком и српском језику у ОШ „10. октобар“ у Суботици, Првој нишкој гимназији „Стеван Сремац“ и Ваљевској гимназији, а четврти представља закључак и даје смернице за наставак двојезичног образовања у Србији. 
БИЛИНГВАЛНА НАСТАВА НА НЕМАЧКОМ И СРПСКОМ ЈЕЗИКУ...

\section{1. Језичка политика Европске уније}

Мото Европске уније Уједињени у различитости ${ }^{3}$, који одјекује у свим сферама друштвеног и политичког живота, односи се пре свега на лингвистичку и културну разноликост које чине саставни део европског идентитета. Добро развијена комуникативна компетенција на неколико језика је тако појединцу неопходна за свакодневно функционисање унутар Уније. У једној мултилингвалној и мултикултурној средини, учење и настава страних језика имају пресудну улогу прво у смислу изграђивања поштовања, разумевања и толеранције, очувања јединства и равноправности, а затим и у очувању језичке разноликости, чији се значај упоређује са биодиверзитетом ${ }^{4}$.

Језичка политика Савета Европе заснована је на три принципа (Савет Европе 2001:2). Први указује да богато наслеђе различитих језика и култура у Европи представља драгоцени заједнички ресурс који треба заштитити и развијати, као и да је неопходан велики напор у образовању како би се те различитости из препреке у комуникацији претвориле у извор заједничког богатства и разумевања. Други принцип наглашава да се само бољим познавањем европских језика може олакшати комуникација и интеракција међу Европљанима који имају различите матерње језике, како би се поспешила европска мобилност, узајамно разумевање и сарадња, превазишле предрасуде и дискриминација. Трећи принцип указује да се државе чланице усвајањем и развијањем националне политике у области учења и наставе модерних језика могу усагласити на заједничком нивоу, континуираном сарадњом и координацијом образовних политика.

Да бисмо разумели европску језичку политику, неопходно је да објаснимо неколико термина. Политика учења страних језика у Европској унији пре свега садржи појам вишејезичности. Вучо (2006: 42) вишејезичност дефинише као способност појединца да узме учешће у интеркултурној интеракцији

3 Енг. United in diversity.

4 О вези лингвистичког диверзитета са биодиверзитетом в. СкутнабКангас 2003. 
на два, три или више језика, на различитим нивоима. Овакво познавање језика појединцу нуди могућност упознавања већег броја културних заједница, размену искустава и шире могућности за радне и људске контакте у оквирима европске заједнице (ibid.). У оригиналном тексту Заједничког европског рефернтног оквира за живе језике (Савет Европе 2001: 4), на енглеском језику се за вишејезичност појављују два различита термина - мултилингвизам и плурилингвизам. Мултилингвизам се објашњава као знање више језика или као постојање различитих језика у неком друштву. Може се постићи једноставно ширењем лепезе језика у понуди у некој школи или образовном систему, подстицањем ученика на учење више од једног страног језика или редуковањем доминантне позиције енглеског језика у међународној комуникацији. Плурилингвизам се односи на језичко искуство појединца у културном контексту, односно на његову способност да током читавог живота у свакодневној говорној пракси користи различите језике које познаје на различитим нивоима комуникативне компетенције (Филиповић 2007: 61). Циљ европских институција објављен у Акционом плану 2004-2006 јесте стварање вишејезичних тј. плурилингвалних појединаца, а то подразумева да поред матерњег језика познају још два страна језика (Европска комисија 2004: 10).

Водич за развој и имплементацију куликулума за плурилингвално и интеркултурално образовање (Савет Европе 2010) ближе дефинише интеркултурну и плурилингвалну компетенцију, не одвајајући познавање језика од културног контекста. Плурилингвална и интеркултурална компетенција јесте способност коришћења вишеструког репертоара лингвистичих и културних ресурса како би се задовољиле потребе за комуникацијом и интеракцијом са људима из различитих средина и другачијег порекла, као и богаћења тог репертоара услед његове употребе. Плурилингвална компетенција односи се на репертоар ресурса које појединац усваја на свим језицима које зна или их је учио и који се такође односи на културе које се доводе у везу са тим језицима (језици у образовању, регио- 
БИЛИНГВАЛНА НАСТАВА НА НЕМАЧКОМ И СРПСКОМ ЈЕЗИКУ...

нални/мањински језици и језици миграција, живи и класични језици). Плурикултуралност упућује на способност учешћа у различитим културама усвајањем неколико језика, док се интеркултурална компетенција даље односи на способност да се искуси културна различитост и оно што је другачије, да се то искуство анализира и из њега извуче корист. Када се једном усвоји, интеркултурална компетенција олакшава разумевање онога што је другачије, успоставља когнитивне и афективне везе између прошлих и нових искустава са различитошћу, посредује између чланова две друштвене групе и њихових култура и преиспитује претпоставке сопствене културне групе и средине (Савет Европе 2010: 8).

Поред идеје о плурилингвизму, познавању више језика (и култура) на индивидуалном плану, Савет Европе паралелно промовише и идеју о лингвистичком диверзитету, међусобно разумевање, друштвену кохезију и демократско држављанство $^{5}$. Друштвена кохезија се овде односи на једнаке могућности за лични развој, образовање, запосленост, мобилност, приступ информацијама и културно богаћење кроз знање језика. Демократско држављанство више није ограничено на концепт „свето тројство“ - језик, нација, држава, већ се остварује учешћем у политичким и друштвеним процесима у вишејезичним срединама, такође захваљујући плурилингвалној компетенцији појединца. Дакле, европско држављанство се односи на партиципацију у свим демократским процесима уз практичну примену језичких знања, утиче на боље разумевање свих заједница и друштвених група као и поштовање језичких права.

\section{1. Билингвизам и билингвална настава - - теоријски оквир}

У контексту европске језичке политике и планирања, билингвална настава је начин за превазилажење баријера унутар мултиетничке Европе и средство којим се практично реализују

5 Језичка образовна политика Савета Европе доступна на адреси https:// www.coe.int/t/dg4/linguistic/Division_EN.asp, приступљено 19. 9. 2017. 
плурилингвистичке тенденције иза којих званично стоје све европске институције. С краја 20. и почетком 21. века појавило се много публикација о различитим облицима двојезичне наставе, али треба истаћи да је ова форма у образовном систему била присутна и много раније. Ауторка Гарсија (2011:29) наводи да су у Алепу пронађене плоче које сведоче о постојању двојезичног образовања пре 4000-5000 година на ебланском и сумерском језику. Римска аристократија се такође образовала двојезично - на латинском и грчком. Којл Бејкер (2011:201) наводи да је билингвално образовање у Европи утемељено још у 19. веку, па је тако у Луксембургу 1843. године забележено и образовање на три различита језика. Бејкер (ibid.) још наводи да су први уџбеници о двојезичној настави забележени у Канади (1917) и Јужној Африци (1926). Америчке дуалне школе су овакав облик наставе имале од 1963, у Ирској датирају од 1922, Велсу од 1939, док у Бугарској и на Малти двојезично образовање настаје током шездесетих година 20. века. Као парадигма првог успешно реализованог билингвалног програма у модерној историји наводи се случај канадског вртића у Сент Ламберту, надомак Монтреала где је 1965. двојезична настава почела да се спроводи на иницијативу родитеља. Уз дозволу локалних власти оформљено је екпериментално одељење од 26 ученика који ће се образовати двојезично на енглеском и нематерњем француском језику како би научили да говоре, читају и пишу на француском, као и да поштују културу и традицију Канађана којима је француски матерњи језик.

Двојезична настава се данас одвија на свим континентима и то на различитим програмима на већинским, мањинским, интернационалним, страним, урођеничким или ревитализованим језицима (Вучо 2007: 2). У вези са тим су и различити циљеви билингвалне наставе у овим земљама, које према Бејкеру (2011: 226) треба сагледати из четири велике перспективе - као део језичког планирања, из перспективе економске исплативости, кроз педагогију, али пре свега политику. У срединама тзв. великих језика циљ двојезичне наставе је пре свега асимилација. У другим може бити уједињење, као што 
БИЛИНГВАЛНА НАСТАВА НА НЕМАЧКОМ И СРПСКОМ ЈЕЗИКУ...

је случај са земљама Европске уније, потом комуникација са спољним светом, одговор на захтеве тржишта рада, очување етничког и верског идентитета, помирење између различитих лингвистичких и политичких заједница, ширење употребе колонијалног језика, јачање елитних група и очување привилегованих положаја у друштву, давање једнаког статуса језицима који у свакодневном животу немају такав статус, продубљивање разумевања језика и културе (Бејкер 2011: 225).

С обзиром на наведене циљеве и мотиве за увођење двојезичне наставе у различите образовне оквире, данас говоримо о неколико појавних облика билингвизма - супрактивни и адитивни, као два доминантна модела у научној литератури, и рекурзивни и динамички, које додатно објашњава ауторка Гарсија (2011: 64). Супрактивни билингвизам се јавља у оним срединама у којима већински језик потискује мањински, односно, тамо где се учењем доминантног језика постепено смањује употреба и на крају заборавља први језик Л1. Резултат је потпуна замена матерњег Л1 страним или доминантним језиком Л2. Пример овог модела налазимо у случају имиграната у САД где влада политика асимилације и где је један од циљева управо брзо смењивање друге двојезичне и стварање треће монолингвалне генерације. Осим тога, случај говорника индијанских језика и њихово образовање у интернатима на територији САД такође говори о асимилационој политици америчких језичких планера, која се оправдава стварањем једнаких услова за напредак за све грађане. Други облик билингвизма је адитивни, који се другачије назива и елитни, а поред поменуте школе у Сент Ламберту у Канади, овај облик двојезичне наставе успешно се спроводио и у скандинавским и земљама Бенелукса (Дурбаба 2011: 224). Код адитивног билингвизма циљ је да говорник буде писмен на два језика не занемарујући притом свој матерњи језик. Елитни билингвизам прати жеља за социјалним успехом и напретком у средини где је за то неопходно знање већинског језика. Рекурзивни билингвизам подразумева могућност ревитализације језика, те тако указује на ситуацију обнављања употребе одређеног језика који је у 
неком периоду био занемарен или потиснут од стране већег или доминантног језика. Поновна употреба језика Маора на Новом Зеланду пример је рекурзивног облика билингвизма где говорници обнављају његово коришћење у различитим традиционалним обредима истовремено му додајући нове функције. Динамички облик билингвизма упоређује се са савременим начином живота и потребама модерног европског друштва које је и само динамично, хетерогено и променљиво. Гарсија (2011: 67) овакву природу двојезичности доводи у везу са европском идејом о плурилингвалном појединцу који је принуђен да свакодневно комуницира у вишејезичној и мултикултуралној средини. Осим поменутих појавних облика билингвизма, неопходно је поменути и оне према критеријуму хронологије усвајања и узраста, као и према критеријуму степена остварене компетенције. Према редоследу усвајања разликују се симултани билингвизам, када родитељи од рођења разговарају са дететом свако на свом матерњем језику, и консекутивни билингвизам, када се особа на неком степену развоја матерњег језика изложи још једном језику. Према узрасту у ком се развија, разликују се рани (симултани или консекутивни) билингвизам и касни билингвизам, који се јавља у ситуацијама када адолесцент или одрасли појединац бива изложен утицајима страног језика, нпр. имигранти прве генерације у новој језичкој средини (Дурбаба 2011: 21). У зависности од степена остварене компетенције постоје симетрични или баласирани билингвизам, што указује на сличан степен развијености оба језика, док је супротан термин асиметрични билингвизам, случај када је један језик више развијен и у већој употреби у односу на други. Семилингвизам је термин који упућује на недовољно развијену компетенцију и на једном и на другом језику.

\section{2. Модели билингвалне наставе}

Различита типологија билингвалне наставе одувек је била везана за идеологију која стоји иза самих програма. Тако, на пример асимилациона политика језичких планера у САД стоји иза транзиционог модела двојезичне наставе. 
БИЛИНГВАЛНА НАСТАВА НА НЕМАЧКОМ И СРПСКОМ ЈЕЗИКУ...

Овај модел промовише значај већинског језика у односу на мањински приказујући га као неопходног за преживљавање у новој језичкој средини. Код транзиционог модела двојезичне наставе наставници или предавачи су најчешће и сами говорници мањинског језика, а њихов је задатак да олакшају и убрзају процес преласка ученика на већински језик. Резултат је стварање једнојезичних појединаца. Поред транзиционог (transitional model), према подели Н. Хорнбергер (Гарсија 2011: 125) постоје и модел одржавања (maintenance model) и модел обогаћивања (enrichment model). Модел одржавања обухвата програме намењене ученицима који настоје да се образују на матерњем језику уз паралелно учење већинског језика. Овај програм се за припаднике националних мањина реализује и у Србији, и то у комбинацији српски и мањински језик, што према Бејкеру представља слаб облик билингвалне наставе. Модел одржавања уопште везује се за етнолингвистичке мањине, за имигрантску групу или домаће становништво чији је језик из одређеног разлога угрожен, као нпр. у случају Индијанаца на територији САД. Модел обогаћивања се не односи само на двојезично образовање мањинских група, већ и локалног становништва и то на страном језику Л2. Циљ овог модела је остваривање функционалне писмености на два или више језика, што представља јачи облик билингвизма или се препознаје као адитивни. Гарсија (2011: 230) наводи два типа овог модела - престижни или елитни и имерзивни. Престижни или елитни билингвизам присутан је код ученика приватних или интернационалних школа који се двојезично образују кроз читав образовни процес. Код имерзивног типа ученици користе страни језик као наставни одређени временски период током школовања. Термин имерзија или урањање (енг. immersion), који се користи од шездесетих година 20. века (Вучо 2006: 49), сликовито описује радно окружење ученика који су у потпуности (100\%) или делимично (до 50\%) изложени страном језику као средству којим долазе до сазнања из различитих области природних и хуманистичких наука. Прва асоцијација на имерзивни билингвалини програм је вртић из Сент Ламберта (Ка- 
нада) и 1965. година од када се успешно реализује двојезична настава на енглеском и француском језику. Овакви програми појављују се у земљама у којима су два или више језика у званичној или службеној употреби. ${ }^{6}$

\subsection{CLIL}

CLIL је акроним преузет из енглеског језика за Content and Language Integrated Learning односно интегрисано учење језика и садржаја. Марш (2002: 58) га дефинише као општи термин који подразумева било коју активност у којој се страни језик користи као средство у учењу нејезичког садржаја у коме и језик и садржај имају заједничку улогу. Далтон-Пафер (2011: 183) CLIL описује као образовни приступ у коме се наставни садржај предаје кроз страни језик као медијум најчешће ученицима који су на неком од три нивоа формалног образовања. Страни језик који се овде користи као инструмент у учењу новог садржаја назива се вехиколарни или посреднички. То је, заправо, радни језик у учионици у којој се реализује двојезична настава. У зависности од временске одређености, у CLIL настави се страни језик може употребити као вехиколарни у потпуности или делимично, тј. до $50 \%$, што је случај и у српским државним школама које су обједињене програмом двојезичне наставе. Ауторка Вучо (2006: 49) примећује да се све време помиње двојезична настава, а не усвајање, што говори о томе да је фокус не на ономе ко прати билингвални програм, већ на онима који тај програм спроводе. Наставници који изводе наставу на страном језику су стручњаци из области природних или друштвених наука који, по правилу, сарађују са наставницима страних језика. Од њих се захтева сертификовано знање страног језика најмање на нивоу Б2. Пре почетка реализације билингвалне наставе, од наставника се очекује да прођу обуку и достигну неопходни ниво како би могли да учествују у овом програму. Трошкове припреме за наставнике најчешће сносе амбасаде или страна представништва који на тај начин промовишу језик и културу своје земље.

6 Шпанија, Велика Британија, Белгија, Финска, Швајцарска итд; 
БИЛИНГВАЛНА НАСТАВА НА НЕМАЧКОМ И СРПСКОМ ЈЕЗИКУ...

У CLIL методи страни језик и садржај који се учи се непрестано прожимају. Нова сазнања се стичу путем Л2, али се истовремено продубљује и знање страног језика. Иако Бејкер (2011: 283) указује на проблем CLIL методе у виду прогресивног јачања рецептивних вештина у односу на продуктивне, неопходно је нагласити да се процес обогаћивања језичког знања ученика неминовно догађа у току двојезичног образовања, као и да се тај процес дешава успут, готово несвесно. Тако можемо говорити не само о учењу, већ и о усвајању релевантне терминологије. Важно је напоменути и да је овај модел заснован на комуникативној компетенцији која истиче друштвено прикладну и сврсисходну употребу језика, односно знање како се језик ефективно употребљава, а не знање о језику (Вучо 2014: 113).

Као што је већ претходно поменуто, идеолошка позадина присутна је и код овог метода учења и наставе страних језика. CLIL осликава идеолошку језичку политику Европске уније, промовише идеју о мултилингвизму и мултикултуралности, припрема европског појединца на живот у вишејезичној средини и формира га за конкурентно мултиетничко тржиште рада. У складу са тим издвајају се бројне предности овог типа двојезичне наставе (Бејкер 2011: 263, Вучо 2006: 52): ширење језичке компетенције ученика на страном језику, развијање креативности и осећаја за комуникацију, веће способности анализирања и решавања проблема, ширење осталих знања равноправно на страном као вехиколарном и на матерњем језику, развијање сигурности личности која влада језицима, веће поштовање себе, флексибилност и прилагодљивост, сигурност у друштвеним интеракцијама, развијање способности за међусобне контакте, успостављање чвршћих веза са појединим и европском друштвеном и културном средином у ширем смислу, стварење мултикултуралног става, поседовање искуства „два језичка света“, олакшана проходност и размена информација у најширем смислу, од породице, заједнице, запослења до међународних контаката у европском и светском контексту, прожимање образовних система земаља учесница у двојезичној настави, трансфер академских знања са једног 
језика на други, дух међународне сарадње у учењу, реципрочно признавање диплома, образовање спремног, отвореног грађанина Европе са израженом толеранцијом и потребом за друштвеном хармонијом.

\section{2. Правно утемељење двојезичне наставе у Србији}

Употреба језика у настави у Србији дефинисана је кроз неколико закона и правилника - Законом о основама система образовања и васпитања (Службени гласник РС, бр. 72/2009), Законом о основном образовању и васпитању (Службени гласник РС, бр. 55/2013), Законом о средњем образовању и васпитању (Службени гласник РС, бр. 55/2013), Правилником о ближим условима за остваривање двојезичне наставе (Службени гласник PC, бр. 105/15) и Правилником о Програму огледа двојезичне наставе у основном образовању и васпитању (Службени гласник PC - Просветни гласник, бр. 6/2004, Службени гласник РС - Просветни гласник, бр. 12/2006). У Закону о основама система образовања и васпитања, у оквиру члана 9 о употреби језика, стоји да се образовно-васпитни рад остварује на српском језику: „За припаднике националне мањине образовно-васпитни рад остварује се на матерњем језику. Изузетно он може да се остварује и двојезично или на српском језику, у складу са посебним законом. Образовно-васпитни рад може да се изводи и на страном језику, односно двојезично, у складу са овим и посебним законом. Образовно-васпитни рад за лица која користе знаковни језик, односно посебно писмо или друга техничка решења, може да се изводи на знаковном језику и помоћу средстава тог језика." Треба нагласити да се закони у образовању веома слабо баве појединостима везаним за двојезично образовање.У највећој мери реч је о билингвалним програмима за мањинско становништво која наставу слушају на матерњем и већинском српском језику. Адитивни билингвизам, односно његов јак облик, који је у српском образовном систему у експанзији, дефинише се путем правилника, а школ- 
БИЛИНГВАЛНА НАСТАВА НА НЕМАЧКОМ И СРПСКОМ ЈЕЗИКУ...

ске управе одређују начине остваривања и прилагођавања оваквог двојезичног образовања кроз школски програм. Закон о основном образовању и васпитању и Закон о средњем образовању и васпитању нешто детаљније указују на услове под којима се настава може одвијати на страном језику. Да би се настава организовала на страном језику, потребно је најмање 15 ученика у групи. Услов је исти за ученике мањинских и немањинских група. Ипак, за припаднике националних мањина могуће је остварење образовно-васпитног рада на мањинском језику и за мање од 15 ученика, уколико Министарство за то да сагласност.

Правилник о ближим условима за остваривање двојезичне наставе из 2015. године даје детаљне смернице за све школе које конкуришу за добијање сагласности за реализацију билингвалне наставе. Двојезична настава може почети у шестом и седмом разреду основне школе, односно од првог разреда гимназије и средње школе. За ученике који конкуришу за овај програм организује се испит у циљу провере знања језика и то кроз четири вештине - читање, слушање, писање и говор. Неопходни ниво познавања језика према Заједничком европском оквиру за живе језике је А1.1 за шести разред, А1.2 за седми, односно А2 за први разред гимназија и средњих школа. Тест за проверу знања ученика израђује Комисија за развој двојезичне наставе, коју именује министар просвете. Наставници који су сагласни да учествују у реализацији билингвалне наставе прихватају све обавезе везане за овај програм и прилажу доказ о познавању језика на ком ће убудуће, поред српског, држати наставу. Познавање језика подразумева сертификовано знање на нивоу Б2 уз обавезу достизања нивоа Ц1 током наредних пет година усавршавања. Правилник такође даје могућност учешћа и оних наставника који су се на том страном језику школовали најмање кроз читаву средњу школу, као и наставника са знањем језика на нивоу Б1 уз заједнички рад са наставником који предаје тај страни језик. Што се тиче начина остваривања двојезичног програма, на страном језику се одређени предмети изводе минимално $30 \%$, а максимално $45 \%$, не рачунајући наставу из предмета Страни језик. 
Правилник о Програму огледа двојезичне наставе у основном образовању и васпитању ступио је на снагу октобра 2006. године. Имајући у виду да тада настава на страном језику на нивоу основног образовања није била законом дозвољена (Вучо 2006:1), основне школе су спроводиле тзв. огледну двојезичну наставу, као што је био случај и са ОШ „Владислав Рибникар“, где се настава и данас одржава на српском и француском језику. Осим начина реализације двојезичног програма, овај Правилник даје смернице и за припрему наставника за билингвални програм. Провера наставника подразумева и држање часа на страном језику пред Комисијом за двојезичну наставу. Осим тога, дефинисано је да наставницима током реализације програма помажу компетентни спољни сарадници или изворни говорници страног језика. Обука наставника такође подразумева унапређење језичке компетенције кроз течајеве страног језика у Републици Србији или земљи изворних говорника тог језика, методичку обуку наставника, сарадњу са интернационалним школама у земљи и другим двојезичним школама у свету. За потребе билингвалне наставе прописује се и адекватно опремање кабинета за двојезичну наставу, као и уџбеничка и дидактичка литература. Културни центри и амбасаде земаља чији језик се користи у билингвалним програмима у Србији финансијски помажу реализацију оваквих видова наставе кроз опремање учионица и обезбеђивање стручних сарадника и изворних говорника7.

Праћење и вредновање свих огледних програма обавља Завод за унапређење образовања и васпитања и Завод за вредновање квалитета образовања и васпитања. Такав је случај и

7 У Правилнику о Програму огледа двојезичне наставе на српском и енглеском у основном образовању и васпитању наводи се сарадња и подршкаод стране наставног кадра Интернационалне школе у Београду, као и спољњих сарадника које обезбеђује Британски савет, амбасаде Уједињеног краљевства, Сједињених Америчких Држава и Канаде у Београду. Школе у којима се двојезична настава одвија на српском и француском језику сарађују са Француском школом у Београду, а амбасада Француске преко Француског културног центра обезбеђује средства за набавку опреме, обуку наставног кадра и литературу. 
БИЛИНГВАЛНА НАСТАВА НА НЕМАЧКОМ И СРПСКОМ ЈЕЗИКУ...

са билингвалним програмима у основним школама у Србији. Тамо где двојезична настава није огледног карактера, вредновање се обавља на нивоу школе у којој се овај вид наставе остварује.

\section{3. Двојезична настава на немачком и српском језику}

Немачки језик је у српском образовном систему присутан од четрдесетих година 19. века (Филиповић и др. 2007: 5), мада се у школама учио и током 17. и 18. века у периодима када је Београд био под аустријском влашћу. Аустријанци и Немци су тада организовали школе на немачком језику. Из Аустроугарског царства долазила је и већина учитеља, први уџбеници, први наставни планови и програми као и закони којима се уређивало школство (Кржељ 2014: 229). Популарност овог страног језика, који у школском систему има дугу традицију у Србији, у сваком тренутку је зависила од друштвено-политичких прилика. Након Првог и Другог српског устанка, у ослобођеној Србији се успоставља школски систем са немачким као првим страним језиком. Оснивањем Велике школе 1863, а затим и Универзитета 1905. године, немачки језик у Србији почиње да се учи и у високошколским установама. На Великој школи постојао је лекторат за немачки језик, а њеним подизањем на ниво европског универзитета озваничена је и Катедра за немачки језик и књижевност (Ђукановић 2016: 31). У периоду између два светска рата, немачки језик је, поред француског, био други страни језик који се најчешће изучавао (Филиповић и др. 2007: 12). Након Другог светског рата, другачији друштвено-политички контекст утицао је на фаворизовање руског и енглеског језика, док француски и немачки постају мање интересантни или благо запостављени. Деведесетих година 20. века српски школски систем на нивоу основног образовања нуди два обавезна страна језика од којих је први енглески, док други заузимају француски, руски или немачки (Филиповић и др. 2007: 13). Данас се може рећи да 
је немачки језик услед друштвено-економских разлога, поред енглеског, страни језик који се најчешће бира за учење, како у формалном основном и средњем образовању, тако и ван њега.

Билингвална настава на српском и немачком језику постоји од школске 2006/2007. године. Данас се она реализује у ОШ „10. октобар“ у Суботици, Ваљевској гимназији, Првој нишкој гимназији „Стеван Сремац“, гимназији „Јован Јовановић Змај“ у Новом Саду, Карловачкој гимназији и у две предшколске установе - вртићу „Палчица“ ПУ „Наша радост“ у Суботици, као и у вртићу „Петар Пан“ у Панчеву. Овде ћемо се бавити реализацијом двојезичне наставе у три школе - ОШ „10. октобар“ у Суботици, Ваљевској гимназији и Првој нишкој гимназији „Стеван Сремац“.

За потребе овог истраживања коришћени су подаци доступни на интернет презентацијама школа, али је такође спроведен и упитник како би се добиле информације од директора и наставника који активно примењују овај облик наставе у учионици. Школе су прво контактиране телефоном, а потом је упитник послат електронским путем на званичну адресу школа 3. јула 2017. Питања су послата у тренутку када наставници нису имали часове, али су још увек завршавали своје обавезе у школама. Свака школа је поново контактирана у септембру 2017 , неколико дана након почетка нове школске године. Иницијална идеја била је да се информације прикупе од што већег броја учесника, али су на крају пристигле свега две електронске поште као јединствени одговори на нивоу целе школе. За једну школу информације су добијене путем телефонског интервјуа. Резултати упитника показали су да је у све три школе билингвални облик наставе препознат као иновативан, пожељан и као освежење у српском школском систему, да се спроводи у складу са релевантним и актуелним законима и правилницима у области образовања, да школе непрестано улажу напоре како би настава била квалитетнија, али и да свака од њих посебно модификује и организује наставу према могућностима, потребама и условима у школи. 
БИЛИНГВАЛНА НАСТАВА НА НЕМАЧКОМ И СРПСКОМ ЈЕЗИКУ...

\section{1. ОШ „10. октобар“ у Суботици}

ОШ „10. октобар“ у Суботици уводи билингвални програм школске 2011/2012. и то на српском и немачком језику, односно на мађарском и немачком. У почетку су програмом били обухваћени ученици првог циклуса образовања и ученици петих разреда, да би од школске 2016/2017. двојезичну наставу слушали и ученици шестих разреда. На основу претходног важећег Правилника о програму огледа двојезичне наставе, настава на немачком и српском је у овој школи почињала од првог разреда, као што је случај и у ОШ „Јован Поповић“ из Новог Сада где се двојезична настава спроводи на српском и руском језику. Наставници ОШ „10. октобар“ бележе одличне резултате ученика који на најранијем школском узрасту са великим интересовањем и лакоћом усвајају градиво на два језика. Примећено је и да су ефекти двојезичног образовања од првог циклуса значајно бољи у односу на резултате које су показали ученици који су у билингвални програм укључени од шестог или седмог разреда. Из тог разлога, ако се узму у обзир постигнућа ученика у раним двојезичним одељењима, наставници и управа ове школе сматрају да је измена првобитног Правилника у погледу полазног узраста за двојезичну наставу велика грешка.

Настава на страном језику у овој основној школи реализује се у обиму $30 \%$ од укупног фонда у првом и другом циклусу основног образовања и васпитања. Часови обраде су у највећој мери на матерњем језику, а часови понављања или утврђивања су често на немачком. Испитивање и оцењивање се врши на матерњем, али се увек појављују бонус питања на немачком језику, чиме се ученицима даје могућност да на тестовима добију додатне поене. У првом циклусу на немачком се уче музичка култура, ликовна култура, физичко васпитање, а настава немачког језика појачана је са још једним часом недељно у односу на уобичајена два, што се остварује као један

8 Подаци о билингвалној настави у ОШ „10. октобар“ у Суботици доступни су на адреси http://www.os10oktobar.edu.rs/index.php/sr/skola-danas/, приступљено 15. 6. 2017. 
час факултативног предмета. Осим тога, ученици имају могућност да немачки уче додатно тј. да се припремају за полагање DSD испита. У другом образовном циклусу се поред наведених предмета двојезично уче и географија и биологија. За сваки предмет одабране су теме које се обрађују двојезично - на немачком и српском тј. немачком и мађарском језику. Школа обилује наставним материјалима за потребе наставе немачког језика, као и двојезичне наставе. У раду са ученицима се користе иновативне методе, а начин учења потпуно је осавремењен уз употребу софтвера посебно урађеног за двојезична одељења.

У Београду је 7. 12. 2012. године између Министарства просвете, науке и технолошког развоја Републике Србије и Амбасаде Савезне Републике Немачке потписан Меморандум о разумевању за полагање испита за стицање DSD дипломе ${ }^{9}$ из немачког језика у 16 школа у Републици Србији у циљу унапређивања учења немачког језика, јачања немачко - српске сарадње у области образовања и подстицања стручног усавршавања наставника у области савремене наставе немачког језика ${ }^{10}$. ОШ „10, октобар“ је 2013. године такође постала партнерска школа СР Немачке потписивањем споразума у вези са наставним предметом Немачки језик као страни заједно са две гимназије у Суботици и четири основне школе. Све школе потписнице споразума обавезале су се да ће на крају образовног циклуса ученици полагати испит за стицање DSD дипломе. Основна школа на крају 8. разреда спроводи DSD испит првог степена. У зависности од остварених резултата на испиту, ученицима се додељују сертификати DSD A2 или DSD диплома

9 Немачка језичка диплома првог степена (DSD, Deutsches Sprachdiplom) је диплома о постигнутом нивоу знања немачког језика, који одговара нивоу Б1 Заједничког европског оквира. Стална конференција министара културе Савезне Републике Немачке додељује је ученицима немачког језика у иностранству и призната је на немачком говорном подручју као званични доказ о познавању немачког језика.

10 Информације о потписивању Меморандума о разумевању о полагању испита за стицање DSD дипломе па адреси http://www.mpn.gov.rs/potpisan-aneks-memoranduma-o-razumevanju-o-polaganju-ispita-za-sticanje-diplome-iz-nemackog-jezika/, приступљено 30. 6. 2017. 
БИЛИНГВАЛНА НАСТАВА НА НЕМАЧКОМ И СРПСКОМ ЈЕЗИКУ...

првог степена, што је једнако нивоу Б1 према Заједничком европском оквиру за живе језике. Сарадња ОШ „10. октобар“ и СР Немачке не обухвата само реализацију двојезичне наставе, већ се остварује и кроз учешће у различитим пројектима из области наставе на српском и немачком, односно мађарском и немачком. СР Немачка кроз различите немачке институције помаже спровођење свих програма обједињених међународном сарадњом, пре свега обезбеђивањем и финансирањем изворних говорника немачког језика који практично помажу наставницима ове школе у организацији и спровођењу билингвалне наставе, а потом и додатном обуком и стручним усавршавањем запослених. Конкретно, за потребе двојезичне наставе у овој школи је тренутно ангажован наставник изворни говорник из СР Немачке и један лектор.

Поред Министарства просвете Републике Србије и СР Немачке, двојезични програм подржава и Покрајински секретаријат за образовање, прописе, управу и националне мањине - националне заједнице који објављује конкурсе за

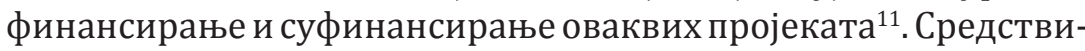
ма Покрајинског секретаријата финансирају се или суфинансирају извршиоци који учествују у реализацији пројекта двојезичне наставе кроз усавршавање у земљи и иностранству, опрема у функцији реализације пројекта, трошкови дидактичког материјала и литература. У току школске године наставници који су укључени у билингвални програм бораве две недеље у СР Немачкој у циљу додатног обучавања и усавршавања знања немачког језика.

Евалуација програма у овој школи врши се у складу са Правилником о програму огледа двојезичне наставе уз надзор Завода за унапређење квалитета образовања и васпитања и Завода за вредновање квалитета образовања и васпитања. Школа

11 Конкурс за финансирање и суфинансирање пројекта Покрајинске владе „Увођење двојезичне наставе на српском и енглеском језику у установе образовања и васпитања на територији АП Војводине“ у 2015. години доступан је на адреси

http://www.puma.vojvodina.gov.rs/etext.php?ID_mat=2174\&PHPSESSID=e8jdbtcmpdaivg6r684qgsdun3, приступљено 29. 6. 2017. 
два пута годишње анкетира родитеље чија су деца укључена у билингвални програм, а на крају сваке школске године Министарству просвете подноси извештај о исходима.

\section{2. Ваљевска гимназија ${ }^{12}$}

Ваљевска гимназија је од школске 2013/2014. укључена у двојезични програм. У овој школи се реализује двојезична настава на српском и немачком, али и на српском и француском језику. Прва генерација која је похађала овај облик наставе све четири године успешно је матурирала у јуну 2017.

Сваке године се на билингвални програм у овој гимназији упише 30 ученика, 15 на српском и немачком и 15 на српском и француском. Школа редовно организује припремну наставу за полагање пријемног испита за овај програм. Ученици који се овде пријављују мотивисани су иновативним методама у настави, идејом да ће стећи релевантно знање из области које их интересују користећи страни језик као вехиколарни, могућношћу да читају одговарајућу литературу на страном језику и идејом да ће лакше уписати факултете у иностранству. Настава на немачком и српском се овде реализује кроз предмете математика, физика, биологија, историја, филозофија и грађанско васпитање и то најмање $30 \%$ од укупног фонда часова. Тај проценат се у току школске године распоређује према расположивом материјалу и значају појединих тема и наставних јединица. Ученици користе литературу предвиђену за образовање у гимназијама, сва наставна средства којима школа располаже, али не и посебне глосаре и материјале који су предвиђени искључиво за билингвалне програме. Наставници ово препознају као кључни проблем у реализацији наставе. Провера знања врши се и у писаном и у усменом облику, на оба језика, у зависности од теме која је обрађена двојезично.

Наставни кадар се за двојезичну наставу припремао уз

12 Подаци о билингвалној настави у Ваљевској гимназији доступни су на адреси http://www.valjevskagimnazija.edu.rs/2010-07-26-14-16-50, приступљено 15. 6. 2017. 
БИЛИНГВАЛНА НАСТАВА НА НЕМАЧКОМ И СРПСКОМ ЈЕЗИКУ...

подршку СР Немачке похађањем течајева немачког језика, полагањем испита на Гетеовом институту, одласком на семинаре о двојезичној настави и стручним усавршавањем у земљи и СР Немачкој. Наставници немачког језика у Ваљевској гимназији блиско сарађују са својим колегама кроз редовно држање часова језика и учешће у припреми наставних јединица на страном језику. Повремено је наставницима доступан и страни лектор, изворни говорник немачког језика који помаже у реализацији саме наставе и припреми часова. У току припремног периода за двојезичну наставу пре конкурисања, у школи је шест месеци боравила волонтерка из Немачке - изворна говорница немачког језика, која је сарађивала са наставницима и ученицима Ваљевске гимназије у циљу боље организације двојезичног програма за наредну годину. Наставници у овој школи су изузетно мотивисани за двојезичну наставу будући да су групе ученика са којима раде мање, жељни су освежења или изазова у настави, а неки по први пут имају прилику на науче француски или немачки језик.

Евалуација двојезичног програма се овде дешава на нивоу школе. Нема екстерног оцењивања ни упоређивања исхода са исходима других школа које такође примењују овај облик наставе. Школа настоји да унапреди сарадњу са школама на немачком говорном подручју, најпре у Баварској, кроз програм размене ученика и конкретне заједничке пројекте, пре свега везане за упознавање традиције, културе и језика два народа, као и у области музике и спорта. Евалуација у циљу побољшања квалитета двојезичне наставе за сада се врши кроз дискусију са колегама и размену искустава са часова.

\section{3. Прва нишка гимназија „Стеван Сремац“13}

Двојезична настава у Првој нишкој гимназији „Стеван Сремац“ уведена је септембра 2014. и спроводи се већ три школске

13 Подаци о билингвалној настави у Првој нишкој гимназији „Стеван Сремац“ доступни су на адреси http://www.sremac.edu.rs/sr/index. php/dokumenta, приступљено 15. 6. 2017. 
године. Идеја и иницијатива за покретање двојезичне наставе на немачком језику потекла је из контаката са представницима Амбасаде СР Немачке у Београду. Прве две године двојезично одељење је имало мањи број ученика (14 и 12), да би почев од прошле године почело да ради пуним капацитетом. Интересовање за двојезичним обликом наставе у Нишу је из године у годину све веће, а све то из жеље за усавршавањем знања немачког језика на сасвим другачији и бољи начин. Велики број ученика осмог разреда је заинтересован за полагање DSD испита и упис у билингвално одељење, а управо је Прва нишка гимназија „Стеван Сремац“ потписница Меморандума о разумевању ${ }^{14}$ у погледу сарадње у вези са наставним предметом Немачки као страни језик са три нишке основне школе. Идеја је да се ученици кроз основну школу припремају за DSD испит, а затим наставе са учењем немачког на високом нивоу и добију DSD диплому. На овај начин се остварује континуиран процес наставе и учења немачког језика у основној школи и гимназији.

На пријемном испиту за школску $2017 / 2018$. годину било је пријављено 38 ученика. Одељење је уписало 26 ученика. Ученици се у двојезично одељење уписују на основу успеха у основној школи, резултата које су постигли на завршном испиту и успеха на пријемном испиту који проверава њихово познавање немачког језика. До сада су сви ученици који се уписују у ово одељење у основној школи имали одличан успех. Што се тиче успеха у гимназији, на крају школске 2016/2017. је од укупно 56 ученика у три разреда са одличним успехом завршило 46, са врло добрим 7, а са добрим 3. Ови подаци директни су показатељи квалитета спровођења наставе у гимназији, што се одразило и на рејтинг саме школе. У циљу боље припреме ученика за пријемни испит, школа пре одржавања испита организује припремну наставу. Такође, за ученике првог разреда двојезичног одељења школа организује додатну наставу немачког језика у циљу уједначавања нивоа њиховог знања и лакшег праћења двојезичне наставе.

14 Информације о DSD дипломи на адреси http://www.sremac.edu.rs/sr/index. php/predmeti/strani-jezici/nemacki/83-dsd-dipl, приступљено 30. 6. 2017. 
Образовно-васпитни рад у одељењима друштвено-језичког смера - немачки језик реализује се по плану и програму за гимназију друштвено-језичког смера. Део наставе изабраних наставних предмета у сва четири разреда, и то најмање $30 \%$ а највише $55 \%$ од укупног фонда часова на годишњем нивоу, реализује се на немачком језику. Предмети из којих се настава изводи на немачком језику су историја, географија, ликовна култура, музичка култура, српски језик и књижевност и информатика. Предметни наставници часове држе на српском језику, а часове или делове часова који се реализују на немачком језику држи лектор за немачки језик, кога школи додељује Амбасада. Лектор има улогу асистента у настави и сарађује са предметним наставницима и наставницима немачког језика у циљу што боље реализације двојезичне наставе. Наставници похађају курс немачког језика како би достигли ниво знања Б1, а у циљу одрживости пројекта у случају одсуства страног лектора. Школа за успешну реализацију двојезичне наставе има подршку Амбасаде Савезне Републике Немачке у смислу обуке наставника у области познавања немачког језика, финансирања боравка наставника на размени и стручном усавршавању у Немачкој, опремања немачког језичког кабинета и набавке наставних материјала. Сви уџбеници на немачком језику који су додељени школи користе се за припрему часова. Ђаци немају одговарајућу литературу на страном језику за сваки предмет који случају двојезично нити глосар са стручном терминологијом, али у највећој мери на часовима уз материјале које им припремају наставници и лектор користе савремене технологије. На располагању су им аудио опрема, пројектор и паметна табла. Испитивање, односно провера знања ученика углавном се реализује на српском језику, писмено и усмено.

Праћење и вредновање двојезичне наставе спроводи руководство школе и Амбасада СР Немачке у Београду преко свог педагошког саветника. Школа Министарству просвете доставља годишњи извештај о реализацији двојезичне наставе која садржи све релевантне информације о овом облику наставе и евентуалне проблеме и потешкоће у процесу реализације пројекта. 
Марија Лончар

\section{4. Закључак}

Двојезична настава на српском и немачком језику у Србији се успешно примењује већ једанаест година, пре свега у гимназијама и основним школама, а потом и у предшколским установама. У овом раду приказане су три образовне установе у којима се реализује билингвална настава на немачком и српском - ОШ „10. октобар“ у Суботици, Ваљевска гимназија и Прва нишка гимназија „Стеван Сремац“. На основу информација добијених из званичних докумената школа доступних на њиховим интернет страницама, као и од наставника и директора запослених у школама, закључак је да се билингвални програми примењују на сличан начин и у складу са усвојеним одредбама из Правилника уз одређене модификације.

Свим наставницима који су укључени у двојезични програм овај облик наставе представља истовремено и велико задовољство и својеврсни изазов. Ученици су у највећој мери вуковци или одлични, па су и услови за рад далеко бољи. Наставници примећују висок степен мотивације код ученика, који осим интересовања за хуманистичке паралелно развијају и интересовање за природне науке кроз страни језик као медијум. Ученици који похађају двојезичну наставу стичу оне вредности које се негују у мултикултуралној и мултилингвалној Европи - разумевање и толеранција према мањинском становништву, развој критичког мишљења, превазилажење предрасуда и отвореност према новим културама.

Недостаци у примени билингвалних програма ипак постоје. Као кључни проблем наставници наводе непостојање одговарајуће литературе за потребе двојезичног образовања. Још увек нема формалних материјала који би се примењивали у школама истог образовног нивоа, као ни речника или глосара са стручном терминологијом из предмета који се изучавају на страном језику. Теме на немачком бирају се према расположивости материјала или значају, што значи да се ученици селективно сусрећу са релевантном терминологијом, а испитивање се углавном врши на матерњем језику. Поред тога, учешће на- 
БИЛИНГВАЛНА НАСТАВА НА НЕМАЧКОМ И СРПСКОМ ЈЕЗИКУ...

ставника у двојезичном програму је неједнако, а праг знања који је потребан за спровођење наставе разликује се у зависности од школе. Тако, у Првој нишкој гимназији наставници још увек не спроводе наставу на немачком, већ то ради страни лектор. Потребна је додатна мотивација кадра за учествовање у овом виду наставе и кроз додатно финансирање и кроз континуирану обуку.

Будући да је овај облик наставе све популарнији и заступљенији у српским школама, претпоставка је да ће се у блиској будућности решити и проблем континуитета двојезичног образовања од најранијег школског узраста. Многе основне школе у Србији немају у свом граду образовну установу на наредном нивоу која ће понудити двојезичну наставу на истом страном језику. Такође, гимназије у којима се спроводи двојезична настава презентују програме и досадашње резултате будућим ђацима из партнерских основних школа, које иначе нису носиоци двојезичних пројеката, али их повезује споразум којим се ђацима омогућава бесплатно полагање DSD испита. Неопходно је и да се у билингвални програм укључе и средње стручне школе ${ }^{15}$, имајући у виду потребе тржишта рада, праћења трендова у бранши, усавршавања, као и успостављања и очувања међународне сарадње између школа. Најзад, контрола квалитета двојезичне наставе је нешто што системски треба решити, најпре формирањем стручног тима за екстерну евалуацију, а потом и интензивирањем истраживачке делатности.

\section{ЛИТЕРАТУРА}

Бејкер 2011: Baker, C. Foundations of bilingual education and bilingualism (Vol. 79). Multilingual matters.

Вучо 2006: Вучо, J. У потрази за сопственим моделом двојезичне наставе, Иновације у настави, 19. Учитељски факултет: Београд, 41-54.

15 Изузетак је Ваздухопловна академија у Београду, у којој се двојезична настава реализује на српском и енглеском језику. 
Вучо 2007: Vučo, J. Dvojezično obrazovanje - savremene tendencije [Bilingual education - modern approaches]. Jezik, književnost, politika [Language, literature, politics], 404-410.

Вучо 2014: Вучо, J. Двојезична настава страних језика у Србији. Филиповић, J. / Дурбаба, О. (ур.) Језици у образовању и језичке образовне политике. Београд: Филолошки факултет, 107-151.

Гарсија 2011: García, O. Bilingual education in the 21st century: A global perspective. John Wiley \& Sons.

Далтон-Пафер 2011: Dalton-Puffer, Ch. Content and Language Integrated Learning: from practice to principles. Annual Review of Applied Linguistics 31, 182-204.

Дурбаба 2011: Дурбаба, О. Теорија и пракса учења и наставе страних језика. Београд: Завод за уџбенике

Ђукановић 2016: Đukanović, J. Jedan vek beogradske germanistike nauka o jeziku u nastavi i naučnom radu (1905 - 2005), u: KostićTomović i dr. (ur.) U carstvu reči - jezici i kulture. Zbornik u čast prof. Jovanu Đukanoviću povodom 85. rođendana. Filološki fakultet, Beograd: FOCUS, 31-38.

Европска комисија 2004: Commission of the European Communities (2003). Promoting Language Learning and Linguistic Diversity: An Action Plan 2004-2006. Brussells, [http://www.saaic.sk/eu-label/ doc/2004-06 en.pdf, приступљено 15.9.2017].

Кржељ 2014: Кржељ, К. Настава немачког језика на нефилолошким факултетима.

Филиповић, J./Дурбаба, О. (ур.) Језици уобразовању и језичке образовне политике. Београд: Филолошки факултет, Савет Европе 2001: Common European Framework for Languages: Learning, teaching, assessment. Strasbourg: Council of Europe Савет Европе 2010: Guide for the development and implementation of curricula for plurilingual and intercultural education. Strasbourg: The Council of Europe.

Скутнаб-Кангас 2003: Skutnabb-Kangas, T. Linguistic Diversity and Biodiversity. The Politics of English as a World Language, 31-52.

Службени гласник РС, Закон о основама система образовања и васпитања, бр. 72/2009, 52/2011, 55/2013, 35/2015 - аутентично тумачење, 68/2015 і 62/2016 - одлука УС.

Службени гласник РС, Закон о основном образовању и васпитању, бр. $55 / 2013$.

Службени гласник РС, Закон о средњем образовању и васпитању, бр. $55 / 2013$.

Службени гласник РС, Правилник о ближим условима за остваривање двојезичне наставе, бр. 105/15. 
БИЛИНГВАЛНА НАСТАВА НА НЕМАЧКОМ И СРПСКОМ ЈЕЗИКУ...

Службени гласник РС - Просветни гласник, Правилник о програму огледа двојезичненаставе на српском и енглеском језику у основном образовању и васпитању, бр. 12/2006.

Службени гласник РС - Просветни гласник, Правилник о програму огледа двојезичне наставе на српском и француском језику у основном образовању и васпитању, бр. 6/2004.

Филиповић 2009: Filipović, J. Мос́ reči: Ogledi iz kritičke sociolingvistike. Zadužbina Andrejević.

Филиповић, Вучо и Ђурић 2007: Filipović, J./Vučo, J. /Đurić, Lj. Critical review of

language education policies in compulsory primary and secondary education in Serbia. Current Issues in Language Planning, Vol. 8:1: 222-242.

\section{ПРИЛОГ}

\section{УПИТНИК ЗА НАСТАВНИКЕ И ДИРЕКТОРЕ - ДВОЈЕЗИЧНА НАСТАВА НА НЕМАЧКОМ И СРПСКОМ ЈЕЗИКУ \\ (послато електронским путем 3. јула 2017. године)}

1. Када је уведена двојезична настава у вашој школи?

2. Који фактори су утицали да двојезична настава буде баш на немачком језику?

3. Да ли је и на који начин увођење двојезичне наставе утицало на рејтинг школе?

4. Колика је била заинтересованост ученика за двојезичну наставу на почетку, а колика је данас?

5. Колико ученика се за двојезичну наставу пријави, а колико их се упише?

6. Какав је општи успех ученика који се упишу на двојезичну наставу?

7. Да ли се у вашој школи организује припремна настава за упис на двојезичну наставу?

8. Да ли је школа у међувремену тражила од Министарства просвете додатне квоте за упис ђака на двојезичну наставу?

9. Чиме су мотивисани ученици за упис у билингвална одељења и која су њихова очекивања?

10. Колико је од прве генерације ученика који наставу слушају двојезично до данас скочио праг за упис на овај програм? 
11. Како су се наставници припремали за реализацију двојезичне наставе тј. шта је подразумевао период обуке наставног кадра?

12. Да ли су наставници током обуке боравили или стручно се усавршавали у некој од земаља немачког говорног подручја?

13. Шта је наставнике мотивисало да наставу почну да држе и на страном језику?/ Које су предности двојезичне наставе за наставнике?

14. Каква је обавеза наставника током распуста у смислу плана и програма као и стручног усавршавања?

15. У којој мери и на који начин професори немачког језика у школи помажу својим колегама у извођењу двојезичне наставе?

16. Да ли ученици за сваки предмет који слушају двојезично имају одговарајућу литературу или глосар са стручним терминима?

17. Које предмете ученици слушају двојезично?

18. Колики је проценат часова одржаних на страном језику у току једне школске године?

19. На који начин професори испуњавају норму од $30 \%$ (или $45 \%$ ) на немачком језику, односно, како се распоређује тај проценат у току школске године?

20. Да ли школа има могућност да реализује програм размене ученика, тј. да ли је до сада остварена сарадња са неком од школа са немачког говорног подручја или са интернационалном школом у Србији?

21. У којим разредима се реализује двојезична настава? (питање се односи на наставнике који раде у основној школи)

22. На који начин се ученици испитују усмено - на српском или на немачком? Како изгледају писмене провере (нпр. да ли је текстуални задатак из математике на страном језику)?

23. Да ли у вашем граду постоји могућност за наставак двојезичног образовања? (питање се односи на наставнике у основној школи у којој постоји двојезична настава)

24. Да ли у вашу школу долазе ученици који су већ у основној школи имали двојезичну наставу? (питање се односи на наставнике у средњој школи или гимназији)

25. Који проблеми у извођењу двојезичне наставе су се јављали до сада у вашој школи?

26. Да ли су наставници који наставу изводе на страном језику и финансијски мотивисани да се додатно ангажују око припреме часова на немачком језику?

27. Да ли је наставницима на располагању лектор или стручни сарадник који помаже у реализацији саме наставе и припреме часова? 
БИЛИНГВАЛНА НАСТАВА НА НЕМАЧКОМ И СРПСКОМ ЈЕЗИКУ...

28. На који начин се изводи евалуација досадашњег рада наставника који учествују у реализацији двојезичне наставе?

29. У којој мери се рад са ученицима из билингвалних одељења разликује од рада са ученицима из осталих одељења?

30. Да ли двојезична одељења имају боље опремљене учионице и боље услове за рад, односно, која наставна средства се користе при извођењу двојезичне наставе?

31. Да ли амбасаде Немачке, Аустрије и Швајцарске активно учествују и пружају подршку за спровођење двојезичне наставе? Како?

\section{Marija Lončar}

\section{BILINGUAL TEACHING IN GERMAN AND SERBIAN: THE EXAMPLES OF ELEMENTARY SCHOOL '10. OKTOBAR' IN SUBOTICA, THE FIRST NIS GYMNASIUM 'STEVAN SREMAC' AND VALJEVO GYMNASIUM}

\section{Summary}

Bilingual teaching in Serbia is the result of the application of modern tendencies of high European institutions with the aim to create plurilingual individuals and a multicultural society. Since its introduction in the Serbian educational system in 2004/2005, this form of teaching has become more popular and its advantages have been recognized by the whole society. A few years ago bilingual teaching started in Serbian and German as well (beside the combinations Serbian - Italian/French/English/Russian) at different educational levels - in elementary schools, grammar schools, and even in kindergartens.

This paper analyses the performance of bilingual teaching in German and Serbian in Elementary School '10. oktobar' in Subotica, The First Nis Gymnasium 'Stevan Sremac'and Valjevo Gymnasium. The results of the teachers and principals who took part in the survey show numerous advantages, but they also portray shortcomings in terms of evaluation, teaching materials and support for teachers, as well as in terms of con- 
tinuous bilingual education. The paper aims to demonstrate the current picture and present challenges related to the implementation of teaching in Serbian and German in order to provide a more systematic approach throughout the bilingual educational process.

Key words: bilingual teaching, bilingual education, vehicular language, CLIL, plurilingualism, multilingualism, multiculturalism, immersion, language education policy. 